\title{
SIMPLIFIED MODEL FOR EVALUATION OF HYDROPOWER PLANT CONVERSION INTO PUMPED STORAGE HYDROPOWER PLANT
}

\author{
S. Kiene*, O. Linkevics \\ Riga Technical University, Institute of Power Engineering, \\ Electrical and Environmental Engineering, \\ 12-1 Azenes Street, Riga, LV-1010, LATVIA \\ *e-mail: santa.kiene@rtu.Iv
}

Increasing capacity of intermittent generation brings new challenges to balance demand and supply in power systems. With retirement of conventional fossil generation, the role of energy storage is increasing. One of the most competitive storage technologies is pumped storage hydropower plant (PSHP). Usually, such PSHPs are constructed as green field solutions, but in some cases conversion of a hydropower plant into a pump storage hydropower plant by building a pump station is possible. To evaluate the feasibility of such modernisation it is necessary to estimate the benefits of PSHP operation. The simplified model was developed for simulation of charging and discharging cycles of PSHP in Latvian power system and trading electricity in Nord Pool power exchange. The nature of this task is stochastic as the price volatility has a trend to increase with expansion of wind and solar power plant capacity. Results of PSHP operation simulation were then used in the economic model to evaluate the feasibility of the proposed conversion.

Keywords: Feasibility of conversion, price volatility, pump station, pumped storage hydropower plant (PSHP), simulation of storage operation. 


\section{INTRODUCTION}

Among other targets, the European Green Deal provides the plan for decarbonisation of energy sector, where the major role is given to renewable energy sources [1]. Without any doubt, it is the right strategy to combat the climate change, but to implement this policy, the industry is facing some technical challenges. One of the most complicated tasks is ensuring the security of electricity supply in the situation of growing capacity of intermittent generation, such as wind and solar. In power system with a high share of wind and solar, there are periods with high output of wind and solar when its capacity may exceed the demand, resulting in electricity prices close to zero or even negative. The opposite situation, which the German Energy Community calls "Dunkelflaute", is the case with low wind and solar and, respectively, with high electricity prices [2]. Decommissioning of existing conventional fossil fuel-based power plant fleet is making the situation even worse, by creating the deficit of backup capacity. In the future energy systems, we are going to see more volatile electricity prices with high peaks and very low or even negative off-peak prices. This creates a very good basis for investments in energy storage solutions, such as a pumped storage hydropower plant (PSHP).

The situation described above is very well illustrated when analysing the correlation between electricity spot prices in Danish price area 1 (DK1) and wind generation output in the Nordic power systems. In Fig. 1, the trend analysis (fifth-degree polynomial) shows that the price is decreasing from about $50 \mathrm{EUR} / \mathrm{MWh}$ in no wind situation to almost zero in maximum wind output [3].

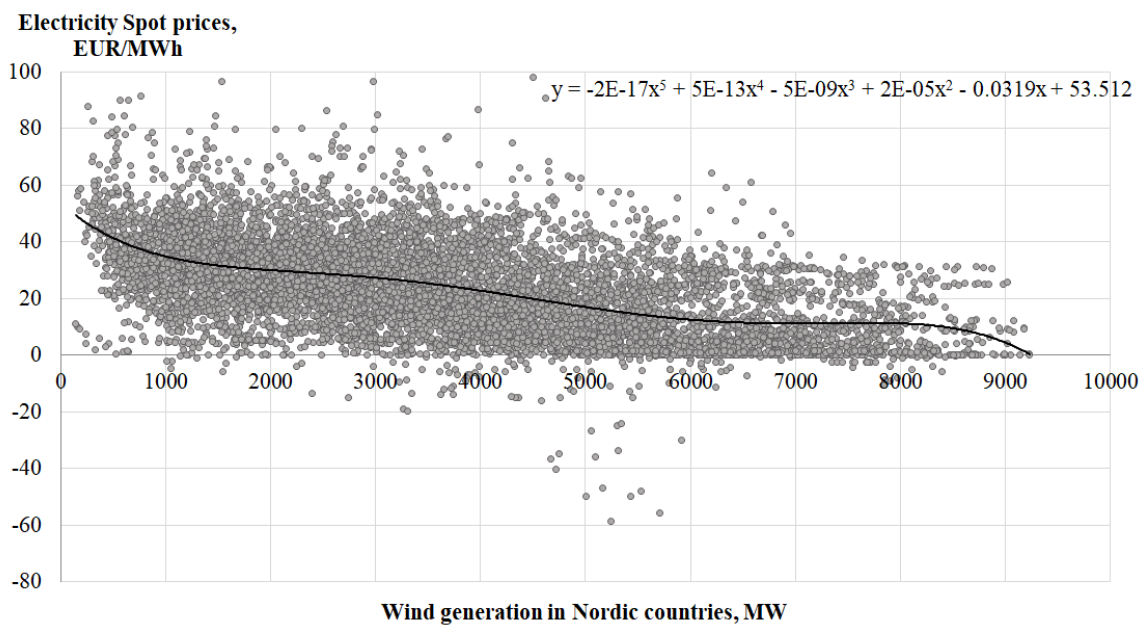

Fig. 1. Electricity prices in Denmark price area DK1 as the function of wind generation output in the Nordic power systems.

Therefore, energy storage has an increasing role to provide a significant integration of the growing share of renewable energy sources and ensure system flexibil- ity and security of supply.

Great contribution to the development of storage optimization models was made by researchers of the Faculty of Electric and 
Environmental Engineering of Riga Technical University. Mathematical model for optimization of Kruonis PSHP scheduling was described and verified in the case study in [4]. An algorithm for storage plant scheduling optimization with a particular focus on market situation in the Latvian bidding area was considered in [5]. The paper [6] presents a stochastic approach to solving a combined optimization problem for short- term scheduling and long-term investment planning of storage power plants for a 30-year long planning horizon. In [7], the stochastic optimization algorithm to solve the complex task of planning the operation of three hydroelectric power plants was proposed based on time average revenue maximisation and considering the random nature of the electricity prices and river water inflows.

\section{PLAVINAS HYDROPOWER PLANT}

Electricity generation of the Latvian hydropower plants provide a large share of renewable energy sources among other European countries [8]. Plavinas hydropower plant (HPP) with its ten hydroelectric units (HG) of Francis type and the installed capacity of $907.5 \mathrm{MW}$ is the largest hydropower plant in the Baltic States and one of the largest in the European Union [9]. Plavinas HPP along with Kegums HPP and Riga HPP is located on the Daugava River, forming the Daugava HPP cascade. Thus, the upper reservoir of Kegums HPP is at the same time the lower reservoir of Plavinas HPP. The first hydroelectric set of Plavinas HPP was launched in 1966, whereas the whole plant was put into full operation in 1968. During the period from 1992 to 2014, the gradual reconstruction of all ten hydroelectric units of Plavinas HPP was performed. At Plavinas HPP, close attention is paid to safety of hydraulic structures. The modernisation of safety monitoring and control equipment has been performed, implementing a computerised system for observation, data collection and processing [10].

There is an urgent need to build an emergency spillway at Plavinas HPP, the necessity of which was emphasised already in 1994. The main objective would be to increase the dam safety level. Necessity of it is explained by stricter EU regulation on probable maximum flood (PMF) values during extreme floods compared to an old USSR regulation being in force at the moment of designing and constructing the Plavinas HPP. Plavinas HPP discharge capacity at the upstream level is not sufficient to discharge the PMF. Therefore, there is a need for additional discharge capacity [10], [11].

The concept of establishing the Plavinas pumped storage hydropower plant envisages the possibility to convert the existing hydropower plant into a PSHP by building a pump station integrated into emergency spillways of Plavinas HPP for pumping water from Kegums HPP reservoir to Plavinas HPP reservoir during off-peak periods with low electricity demand, high surplus of electric capacity and low prices. The accumulated water would then be discharged through the existing Plavinas HPP hydro turbines during high electricity demand and high electricity prices.

One of the factors for successful conversion of Plavinas HPP into a PSHP is that the installed capacity of the existing hydro units (10 units with flow capacity in the range from 260 to $280 \mathrm{~m}^{3} / \mathrm{s}$ each) is too high compared with the normal Daugava inflow, 
and for this reason there is an additional reserve for draining the amount of water through the units, which can be provided by the construction of a pumping station.

\section{PSHP MODELLING}

The parameters of Plavinas and Kegums HPP reservoirs used in the calculations of the PSHP operating mode are given in Table 1. Permissible levels in reservoirs are an important factor in modelling the possi- bilities of hydro storage. It should also be considered that the hydropower plant operates at peak loads and free water flow in the downstream reservoir is not provided.

Table 1. Data of Plavinas HPP Reservoir and Hydraulic Structures [10]

\begin{tabular}{|l|c|}
\hline Rated electrical power, MW & 907 \\
\hline Number of hydro units & 10 \\
\hline Average perennial electricity generation, GWh & 1586 \\
\hline Average annual inflow, $\mathrm{m}^{3} / \mathrm{s}$ & 576 \\
\hline Normal water level of upper reservoir (NUL), $\mathrm{m}$ & 72.0 \\
\hline Minimal water level of upper reservoir, $\mathrm{m}$ & 67.0 \\
\hline Average water level of upper reservoir, $\mathrm{m}$ & 69.0 \\
\hline Water head at NUL, $\mathrm{m}$ & 40 \\
\hline Upper reservoir 1-meter volume AB, mln. $\mathrm{m}^{3}$ & 28.78 \\
\hline Lower reservoir 1-meter volume LB, mln. $\mathrm{m}^{3}$ & 23.44 \\
\hline Minimum water level of lower reservoir, $\mathrm{m}$ & 30.4 \\
\hline
\end{tabular}

The operational condition of hydroelectric power plants mainly depends on water inflow in the Daugava River, which has a distinctly seasonal character - the lower inflow is in summer and winter periods, while during spring floods it is the highest. Water supply is very uneven, both over several years and over one year. The unevenness of this inflow must be taken into account when modelling the operation of the pumping station, as there may not be available hydroelectric units for additional electricity generation in high water inflow periods, while during low-water periods there may not be enough water for pumping.

According to the information of Latvenergo JSC, in 2004 the suitability of Kegums HPP and Plavinas HPP reservoirs for hydro accumulation was assessed. Within the framework of the Plavinas HPP emergency spillway study, the possibility of integrating a pumping station into the reserve spillway was assessed. From an economic point of view, a pumping flow of $80 \mathrm{~m}^{3} / \mathrm{s}$ provided by two pumping units is the most technically advantageous option. Fluctuations in reservoir levels caused by pumping are not significant in either Plavinas HPP or Kegums HPP reservoir. Neither dam structures nor gates or any other element of the system are subject to significant loads that may result from pumped storage operation [10].

Thus, a pumping station built into an emergency spillway has an advantage in terms of the investment that would be required to accomplish a green field project. A large part of the investments (such as acquisition of land from owners, mobilisation of the project, most of the construction 
works, transfer of works) that are attributable to the preparation of construction site should not be attributed to the construction project of Plavinas HPP pumping station. However, the existing infrastructure needs to be considered - the capacity of the pumping station is limited by the permissible levels of reservoirs.

According to the technical estimates, the pumping station with a pumping flow of $80 \mathrm{~m}^{3} / \mathrm{s}$, provided by two units, has an electrical load of $36 \mathrm{MW}(2 \times 18 \mathrm{MW})$ and a total efficiency of $84.6 \%$. If one specific hydro unit with a capacity of $90 \mathrm{MW}$ is selected for generation, then the technical parameters of the possible Plavinas PSHP are given in Table 2.

Table 2. Plavinas PSHP Technical Parameters [10]

\begin{tabular}{|l|c|c|}
\hline Parameters & Pumping & Generation \\
\hline Water head, $\mathrm{m}$ & 39 & 35 \\
\hline Water consumption, $\mathrm{m}^{3} / \mathrm{s}$ & 80 & 284 \\
\hline Water consumption in 1 hour, thousand $\mathrm{m}^{3}$ & 288 & 1022 \\
\hline Installed electrical power (input/output), MW & 36 & 90 \\
\hline Efficiency, \% & 84.6 & 92.6 \\
\hline
\end{tabular}

Considering the technical parameters of the hydroelectric units, the pumping station should operate for at least 3.5 hours to provide water for the operation of the HG with a nominal capacity for one hour. Thus, the total PSHP efficiency can be calculated as:

$\eta_{H P S P}=P_{\text {gnom }} /\left(\frac{Q_{\text {gen }}}{Q_{\text {pump }}} \cdot P_{\text {pump }}\right)$, where

$P_{\text {g nom }}, P_{\text {pump }}-$ the rated electrical power of the selected hydroelectric unit and pump station, respectively, $\mathrm{MW} ; Q_{\text {gen }}, Q_{\text {pump }}-$ water consumption of the hydroelectric unit of HPP and pumps of pumping station, respectively, $\mathrm{m}^{3} / \mathrm{s}$ (from Table 2 ).

\section{ELECTRICITY PRICE ANALYSIS: FACTS AND FORECAST}

Pumped storage hydroelectric power plants are mainly used for peak load shaving or the so-called energy arbitrage. This means buying low-cost electricity for pumping when demand is low and selling electricity at a higher price during peak demand.

Electricity prices in the Latvian price area of the Nord Pool Spot power market have been analysed for the past 3 years [3]. The respective price duration curves are shown in Fig. 2. In 2020, negative prices appeared in the Latvian price zone for the first time. However, in general the price duration curve was flatter than in previous years - prices above $50 \mathrm{EUR} / \mathrm{MWh}$ appeared 944 hours, while in 2019 and 2018 3255 hours and 3846 hours, respectively. The maximum price peaks reached 200 EUR/MWh similarly as in 2019, while the maximum price in 2018 reached $255 \mathrm{EUR} /$ MWh. In 2020, prices below 35 EUR/MWh appeared around 4900 hours, in 2019 around 1800 hours and in 2018-1177 hours. In 2020, the average electricity price was the lowest - 33 EUR/MWh, which could be explained by lower electricity demand due to Covid-19. However, in the future, with the changing growth of wind and solar power plants in the Baltic region, greater 
price fluctuations are expected, which may payback performance of PSHP [6], [11]. have a positive impact on the economic and

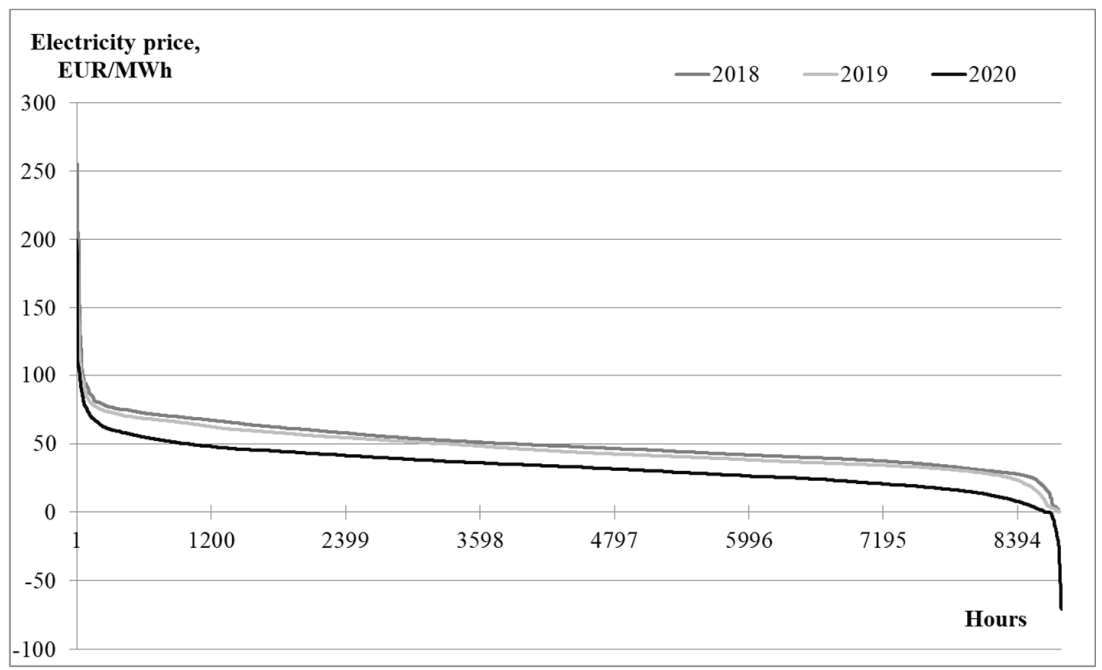

Fig. 2. Nord Pool Spot electricity price duration curves in the Latvian price area.

In order to make the forecast of electricity prices in the Baltic States, we shall simulate the effect of increasing wind capacity from existing $924 \mathrm{MW}$ (EE: $320 \mathrm{MW}$, LV: $66 \mathrm{MW}, \mathrm{LT}: 548 \mathrm{MW}$ ) to $2500-5500 \mathrm{MW}$ in 2030 [12]-[14]. The projected increase of wind capacity will result in higher price fluctuation. For the purposes of our analysis, we modified electricity price profiles. The principle of this modification is illustrated in Fig. 3. We reduced the lowest daily electricity prices to widen the difference between high and low prices.

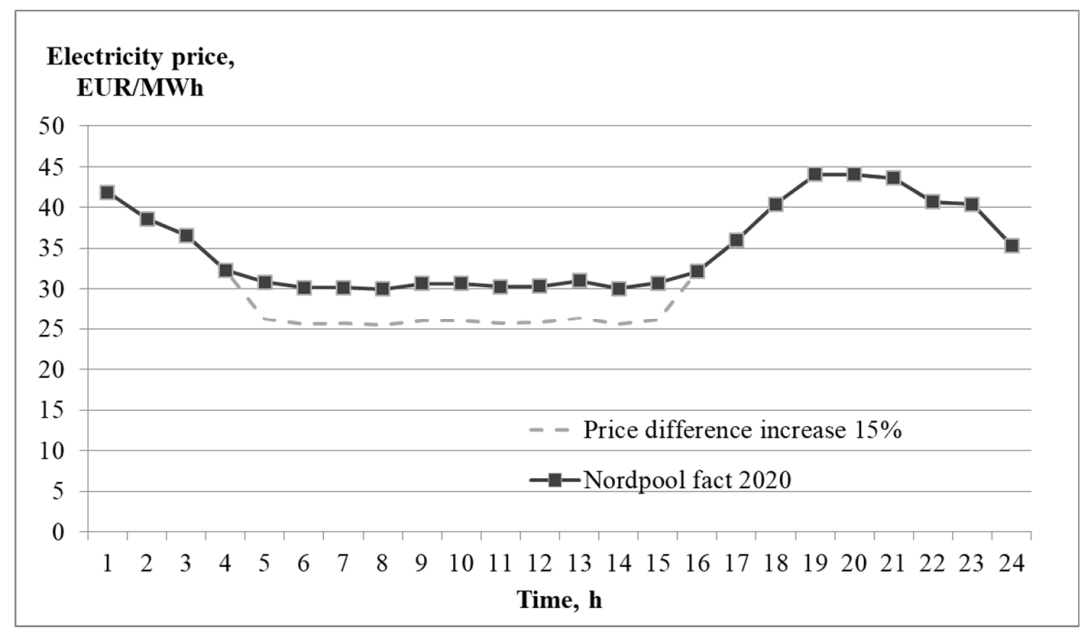

Fig. 3. Modification of electricity price profiles to take higher intermittent generation capacities. 
Taking into account all the above data, as well as using historical data on the actual operation of hydroelectric units, reservoir downstream and upstream levels, and electricity prices on the Nord Pool Spot, we simulated the combined operation of the pumping station and existing hydroelectric units of Plavinas HPP. A simplified modelling algorithm for the determination of PHSP operating condition is shown in Fig. 4.

Based on the hourly electricity price data, the daily maximum price is determined and the price ratio $N$ is calculated as:

$N=C(t) / C_{\max }$,

where

$\mathrm{C}(\mathrm{t})$ - the actual price at time $\mathrm{t}(\mathrm{t}=1 \mathrm{~h})$.

The efficiency of the PSHP calculated according to Eq. (1) is $70 \%$, which determines the price ratio at which it would be useful to buy electricity for pumping and selling electricity on the exchange. At the price ratio $\mathrm{N}<70 \%$ pumping is provided, while during the daily peak load at high prices $\mathrm{N} \geq 95-100 \%$ generation is provided.

Before starting the operation of the pump, the permissible upper $(\mathrm{AB})$ and lower (LB) reservoir levels, as well as the actual operation of the generators at Plavinas HPP $\left(\sum P_{\text {gen }}=0\right)$ are checked. This means that the pumping station can only be operated when the hydroelectric units are still. If the permissible values are not exceeded, the pump with the rated electric power $P_{\text {pump }}$ is operated.

The amount of water $W_{\text {pump }}$ obtained during pumping is:

$$
W_{\text {pump }}(t)=Q_{\text {pump }} \cdot t \text {. }
$$

Plavinas HPP hydroelectric units have a technically permissible range within which they can operate. In this case, the minimum electrical power $P_{\text {gen min }}$ of the generator is $65 \mathrm{MW}$, which corresponds to the water consumption of the turbine $Q_{\text {gen } \min }\left(\mathrm{m}^{3} / \mathrm{s}\right)$ determined according to Eq. (4):

$$
P_{\text {gen } \min }=9.81 \cdot h \cdot Q_{\text {gen } \min } \cdot \eta_{\text {gen }},
$$

where

9.81 - gravitational acceleration, $\mathrm{m} / \mathrm{s}^{2} ; \mathrm{h}-$ water head of Plavinas HPP, m; $\eta_{\text {gen }}-$ efficiency of $\mathrm{HG}, \%$ (see Table 2 ).

The pumped water volume is compared with the minimum water volume required for the operation of the hydraulic unit:

$W_{\text {pump }}(t) \geq Q_{\text {gen } \min } \cdot t$.

The operation of the hydraulic unit is activated depending on the available water volume $W_{\text {pump }}(t)$ at the price ratio $\mathrm{N} \geq$ $99 \%$, which corresponds to the daily maximum price:

$$
P_{\text {gen }}(t)=\left\{\begin{array}{c}
P_{\text {gen min }}, W_{\text {pump }}(\mathrm{t})=W_{\text {gen min }} \\
9.81 \cdot h \cdot \frac{W_{\text {pump }}}{t} \cdot \eta_{\text {gen }}, W_{\text {gen min }} \leq W_{\text {pump }}(t) \leq W_{\text {gen }}, \\
P_{\text {gnom }}, W_{\text {pump }}(t)>W_{\text {gen }}
\end{array}\right.
$$

where

$W_{\text {gen }}=Q_{\text {gen }} \cdot t-$ water volume required for one-hour operation of the hydroelectric unit at rated capacity, $\mathrm{m}^{3}$. 


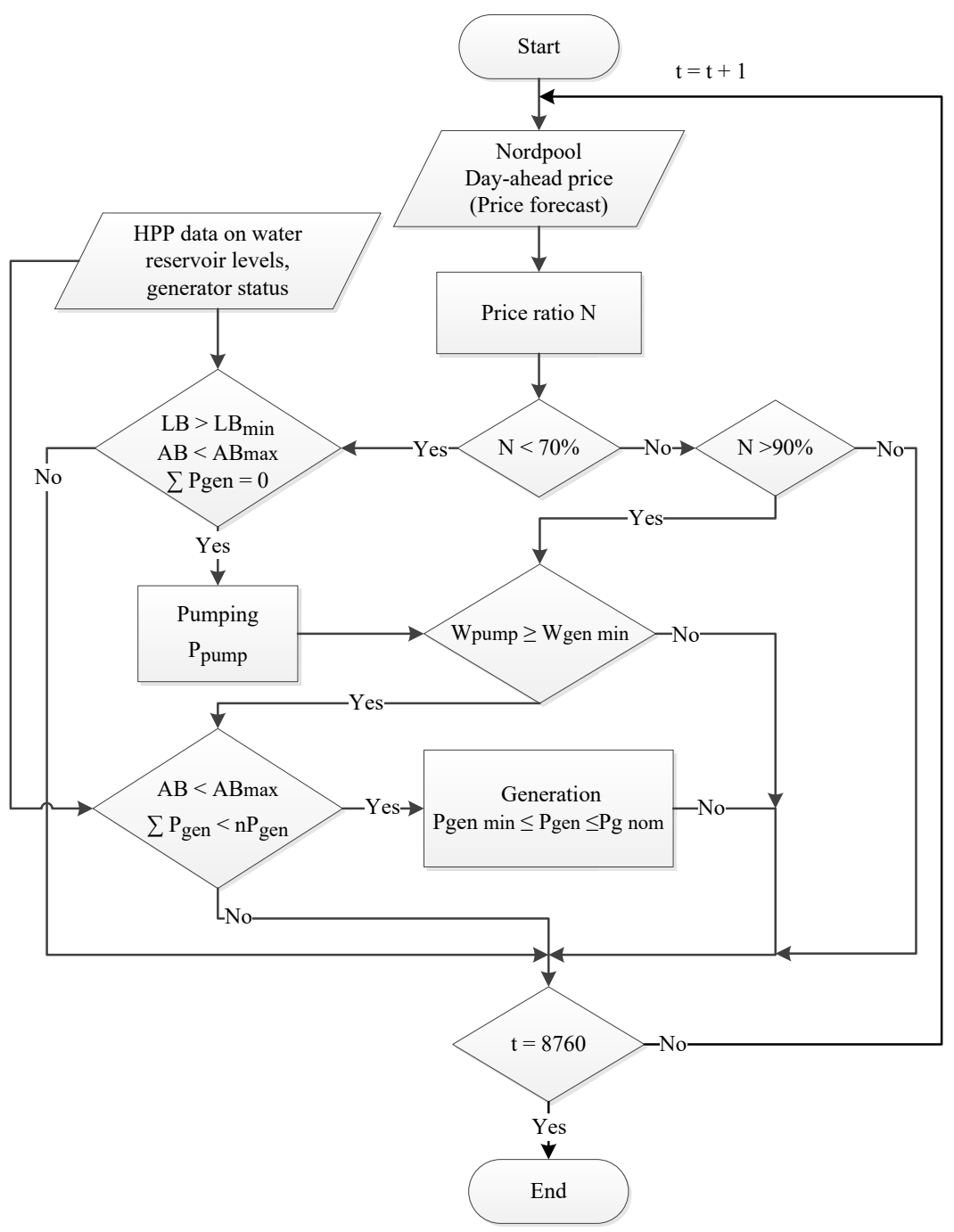

Fig. 4. Simplified algorithm for calculation of PSHP operating regime.

As in case of pumping, the limitations of the water level of upper reservoir and the availability of hydroelectric units for generation are taken into account before operating the HG. In cases when the price peak is highly expressed, the algorithm predicts the operation of several generators simultaneously $n \cdot P_{\text {gen }}$, where $n$ is the number of hydroelectric units operated simultaneously:

$$
n=W_{\text {pump }}(t) / W_{\text {gen }} .
$$

During the modelling, the permissible levels of reservoirs are observed, the change of which is calculated as:

$$
\begin{aligned}
& \triangle A B(t)=W_{\text {pump }}(t) / W_{H P P A B}, \\
& \Delta L B(t)=W_{\text {pump }}(t) / W_{H P P L B},
\end{aligned}
$$

where

$\triangle \mathrm{AB}$ and $\triangle \mathrm{LB}$ - changes in upstream and downstream water levels of Plavinas HPP, respectively, m; $W_{H P P A B}$ and $W_{H P P L B}-$ water volume of 1 meter at upstream and downstream reservoirs of Plavinas HPP, respectively, $\mathrm{m}^{3}$ (see Table 1 ). 


\section{RESULTS AND DISCUSSION}

Performing simulation according to the developed algorithm and historical electricity price data of Nord Pool Spot for 2020, PSHP daily operating modes were obtained. The daily operating mode of Plavinas HPP on the example of 28 January is shown in Fig. 5. In this example, the PSHP operated in pumping mode for 5 hours at a relatively low price and consumed $180 \mathrm{MWh}$ of elec- tricity, providing water for the operation of the generator during peak load. In this particular example, the hydro unit could operate for two hours generating $180 \mathrm{MWh}$ of electrical energy. It can be seen that electricity prices remained high in the coming hours, so pumping stopped. In this example, the daily income of Plavinas HPP would be around $3100 \mathrm{EUR}$.

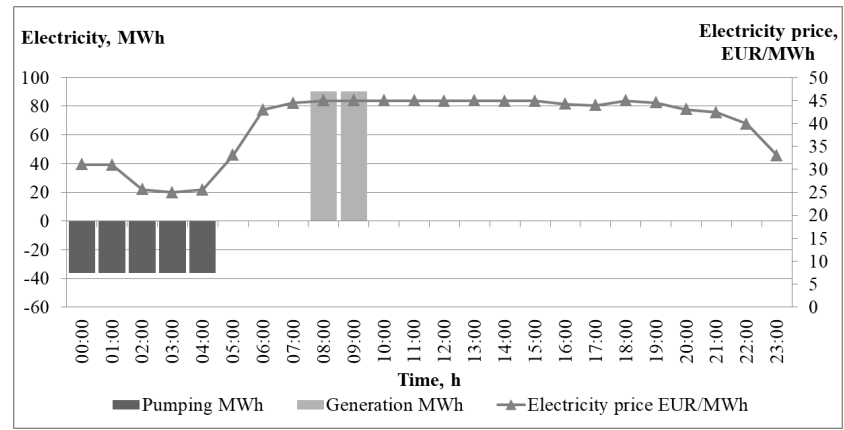

Fig. 5. Plavinas PSHP daily operation mode (28 January).

The operating modes of PSHP during the year are shown in Fig. 6. It can be seen here that no pumping takes place during the flood period (March to April). The water inflow into the Daugava exceeds $1000 \mathrm{~m}^{3} / \mathrm{s}$ and at night it provides a sufficient amount of water for the operation of all Plavinas HPP hydroelectric units during peak hours.
According to the simulation data, on average there were 2 hydroelectric units used for generation daily. The average daily additional peak capacity gain is $180 \mathrm{MW}$. In total, during the year about $60 \mathrm{GWh}$ of electricity was generated in addition to the existing operation of Plavinas HPP, while consuming approximately $80 \mathrm{GWh}$ of electricity in the pumping mode.

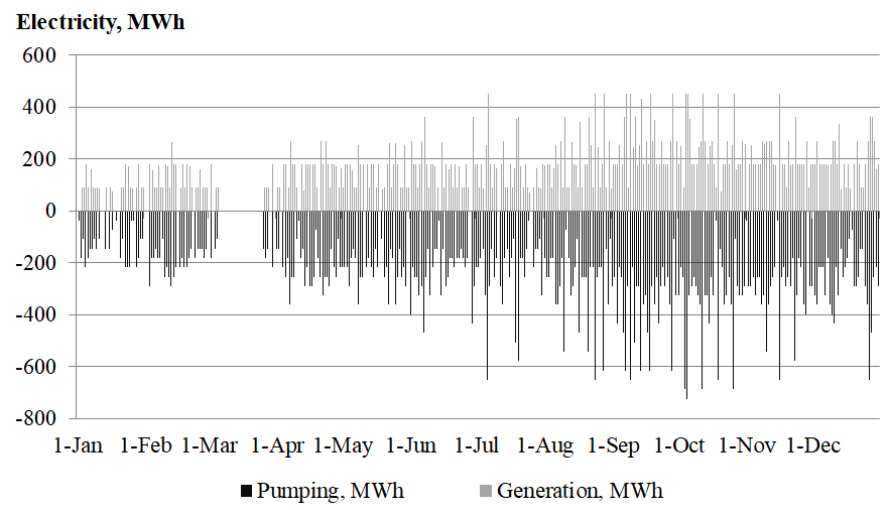

Fig. 6. Annual operation of Plavinas PSHP. 
As a result of operation of the pumping station, the maximum change of the water level is $+0.300 \mathrm{~m}$ in Plavinas HPP reservoir and $-0.369 \mathrm{~m}$ in Kegums HPP reservoir. The permissible levels of the upper and lower reservoirs were not exceeded. Changes in the upper water reservoir levels during the pump operation are shown in Fig. 7. There were 28 hours/year when the operation of the pumping station had to be limited due to the maximum allowable water level in the upstream reservoir. It should be considered that with the pumping of water from the lower reservoir of Plavinas HPP, the amount of water available for the operation of Kegums HPP is reduced. In some cases of low water inflow, the operation of Kegums HPP may be affected. In this case, the operation of the pumping station should be limited, which would reduce the potential profit of the PSHP.

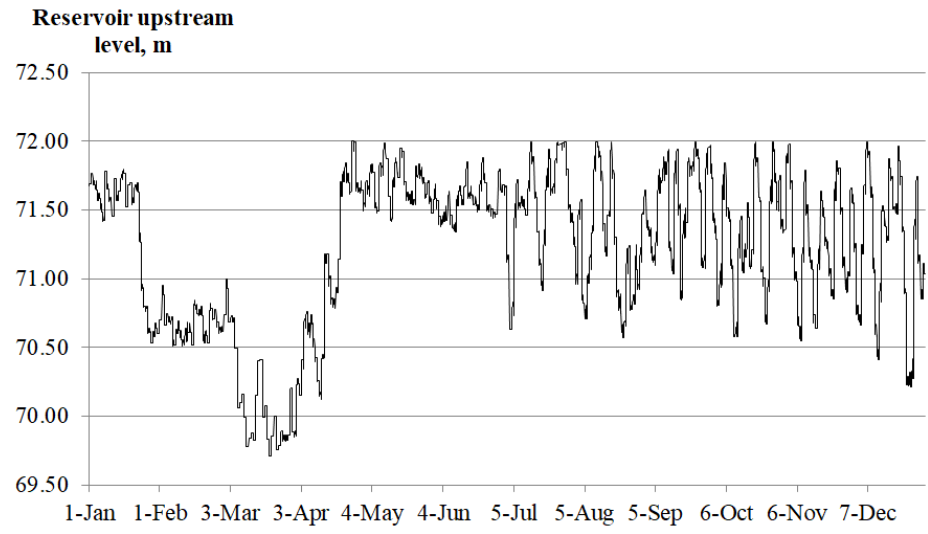

Fig. 7. Plavinas HPP upper reservoir water level fluctuations.

\section{ECONOMIC ASSESSMENT}

In 2004, the capital costs of the pumping station were estimated as additional costs for the Plavinas HPP emergency spillway in the amount of approximately 21 million EUR [10], [11]. Considering the construction cost growth index available at the Central Statistical Bureau [15], the costs of the pumping station today could amount to around 43 million EUR (specific capital costs around 1200 EUR/kW). Operating costs are assumed to be $1.75 \%$ of capital costs, amounting to approximately 760 thousand EUR/year. The discount rate is assumed to be $5 \%$.

Economic calculations showed that the daily price difference on the Nord Pool Spot market, which was around $30 \%$ on average over the last three years, is not sufficient to ensure the capital investment return on the Plavinas HPP project. The possible profit from the operation of PSHP is about 800 thousand EUR.

In order to simulate possible future situation with high price fluctuations, we used the modified price curve with an increased price difference between the daily maximum and minimum prices. By increasing price difference up to $40 \%$, we observed significant improvement of the economic indicators of PSHP. Table 3 shows various values of price differences and the corresponding income, as well as the co-financing required to pay off the project over 30 years. 
Table 3. Some of the PSHP Economic Indicators at Various Price Differences

\begin{tabular}{|l|c|c|c|}
\hline Average price difference, $\%$ & $37 \%$ & $39 \%$ & $40 \%$ \\
\hline Income, million EUR & 1.2 & 1.4 & 1.5 \\
\hline Subsidy, \% & $85 \%$ & $75 \%$ & $70 \%$ \\
\hline
\end{tabular}

As we can see, at average price difference of $40 \%$ the annual profit increased to 1.5 million EUR, which can be returned in 30 years if $70 \%$ of investment is subsidised.

It should be noted that the main limitation of PSHP projects is the uncertainty about their future income. However, in addition to peak load balancing, storage can provide a number of other functions that do not currently have a revenue stream but have an economic value. First, the performance of thermal power plants is optimised by reducing the need for changes in their capacity or start-up and shut-down times [16], [17]. The cost savings in this case are not considered in the PSHP economy. Second, the non-revenue benefit of PSHP is the delivery of the necessary additional benefits to the network, which currently does not have a market price, such as fast and ultra-fast ramp rates in capacity. It is very important for PSHP project developers to find a way to gain the income of these last two benefits.

\section{CONCLUSIONS}

The authors have come to the following conclusions:

1. Further improvement of the proposed algorithm for calculation of PSHP operating regime is possible to ensure variable pumping and generation capacity of PSHP.

2. The algorithm for optimisation of PSHP operation has been implemented using MS Excel software and integrated with economic model. To improve the proposed calculation method, it is supposed to reproduce the model in more advanced software, for example MatLab.

3. Plavinas PSHP with the pumping capacity of $80 \mathrm{~m}^{3} / \mathrm{s}$ can provide the amount of stored electricity around $60 \mathrm{GWh}$ per year, while consuming approximately $80 \mathrm{GWh}$ of electricity in pumping mode. The availability of electrical capacity to cover peak loads is increased by an average of $180 \mathrm{MW}$.
4. The difference in historical hourly electricity prices of Nord Pool Spot has not been sufficient to ensure the recovery of the capital costs of PSHP development.

5. A favourable market for the high economic efficiency of PSHPs is the one with large hourly price differences between low price and high price. In the future, with the increasing share of renewable energy sources, higher price differences are expected.

6. The economic benefits of PSHPs should be assessed appropriately in terms of the additional value they could bring to the energy system.

7. Pumping of water from the lower reservoir of Plavinas HPP in particular lowwater periods may disturb the operation of Kegums HPP by limiting the amount of available water. It would be necessary to additionally assess whether restrictions on the operation of Kegums HPP are being created. 
The article has been supported by the Latvian Council of Science, project "Management and Operation of an Intelligent Power System (I-POWER)" (No. lzp-2018/1-0066) and by the Ministry of
Economics of the Republic of Latvia, project "Future-proof Development of the Latvian Power System in an Integrated Europe (FutureProof)", project No. VPP-EMINFRA-2018/1-0005.

\section{REFERENCES}

1. European Commission. (n.d.). A European Green Deal. Available at https://ec.europa. eu/info/strategy/priorities-2019-2024/ european-green-deal_en

2. Li, B., Basu, S., Watson, S., \& Russchenberg, H., (2020). Mesoscale Modeling of a 'Dunkelflaute' Event. Wind Energy. John Willey \& Sons Ltd. 10.1002/we.2554

3. Nord Pool Group. (n.d.). Nord Pool Market Data. Available at https://www. nordpoolgroup.com/Market-data1/Powersystem-data/

4. Baltputnis, K., Sauhats, A., \& Linkevičs, O. (2016). Potential for energy storage in Latvian and Lithuanian price area in the Nord Pool Spot. In IRES 2016, 10th International Renewable Energy Storage Conference, (pp. 1-10), 15-17 March 2016, Düsseldorf Germany.

5. Baltputnis, K., Broka, Z., Sauhats, A., \& Petričenko, R. (2016). Short-term optimization of storage power plant operation under market conditions. In 2016 IEEE 16th International Conference on Environment and Electrical Engineering (EEEIC 2016), (pp. 250-255), 7-10 June 2016, Italy, Florence. doi:10.1109/ EEEIC.2016.7555466

6. Sauhats, A., Coban, H., Baltputnis, K., Broka, Z., Petričenko, R., \& Varfolomejeva, R. (2016). Optimal Investment and Operational Planning of a Storage Power Plant. International Journal of Hydrogen Energy, 41 (29), 12443-12453. doi: 10.1016/j.ijhydene.2016.03.078

7. Sauhats, A., Varfolomejeva, R., Petrichenko, R., \& Kucajevs, J. (2015). A stochastic approach to hydroelectric power generation planning in an electricity market. In IEEE 15th International Conference on Environment and Electrical Engineering (EEEIC 2015), (pp. 883-888), 10-13 June 2015, Rome, Italy. doi:10.1109/ EEEIC.2015.7165280

8. Eurostat. (n.d.). Renewable Energy Statistics. Available at https://ec.europa. eu/eurostat/statistics-explained/index.php/ Renewable_energy_statistics

9. Latvenergo. (n.d.) Latvenergo Group Generation. Available at https://latvenergo. lv/en/par-mums/razosana

10. Latvenergo. (2015). Plavinas HPSP Assessment: Pumping Station Built-in Plavinas HPP Emergency Spillway. Riga: Latvenergo. (in Latvian)

11. Zvirgzdins, J., \& Linkevics, O. (2020). Pumped-Storage Hydropower Plants as Enablers for Transition to Circular Economy in Energy Sector: A Case of Latvia. Latvian Journal of Physics and Technical Sciences, 57 (3), 20-31. doi: https://doi.org/10.2478/ lpts-2020-0012

12. Elering. (2020). Estonian Electricity System Security of Supply Report 2019. Available at https://elering.ee/sites/default/files/public/ varustuskindluse $\% 20 \mathrm{konverentsid/SOS \%}$ 202019\%20ENG.pdf 
13. Augstsprieguma tikls. (2020). Annual Statement of Transmission System Operator for the Year 2019. Available at https://www. ast.lv/en/content/tso-annual-statement

14. Litgrid. (2020). Development Plan of the Electric Power System and Transmission Grid 2020-2029. Available at https://www. litgrid.eu/index.php/grid-development/-electricity-transmission-grid-ten-yeardevelopment-plan/3851

15. Central Statistical Bureau of Latvia. Available at https://www.csb.gov.lv/lv/ statistika/statistikas-temas/ekonomika/ razotaju-cenas/tabulas/rcg060/buvniecibasizmaksu-indeksi-pa-resursu-veidiem
16. Ivanova, P., Sauhats, A., \& Linkevics, O. (2016). Towards optimization of combined cycle power plants' start-ups and shut-down. In 57th International Scientific Conference on Power and Electrical Engineering of Riga Technical University (RTUCON 2016), 13-14 October 2016, Riga \& Cesis, Latvia. doi:10.1109/RTUCON.2016.7763081

17. Ivanova, P., Sauhats, A., \& Linkevics, O. (2019). District Heating Technologies: Is it Chance for CHP Plants in Variable and Competitive Operation Conditions? IEEE Transactions on Industry Applications, 55 (1), 35-42. 